\title{
A versenyképesség hatása a logisztikai teljesítményre - különös tekintettel a visegrádi országokra
}

\begin{abstract}
Kutatásunk célja annak vizsgálata, hogy az országos versenyképesség jellemzésére használt globális versenyképességi index 12 pillére közül melyek fejlesztésével érhető el előrelépés a visegrádi országok logisztikai teljesítményében és az azt jellemző, logisztikai versenyképességet mérő index értékében. Ennek érdekében elemeztük a versenyképességi index pillérei és a logisztikai versenyképességet mérö index alkotóelemei közötti kapcsolatot, valamint azt, hogy miként határozza meg a versenyképesség a logisztika fejlettségét. A visegrádi négyek versenyképességi pillérekre alapozott logisztikai fejlesztésének vizsgálatát objektív indexértékek alapján, valamint a logisztikai versenyképességi rangsor elején álló országokkal összehasonlítva tekintettük át. Eredményeink alapján fogalmaztuk meg a visegrádi országok számára a logisztikai teljesítményt fokozó javaslatainkat, valamint azokat a közösen megvalósítható változtatásokat is, amelyek kihasználásával a visegrádi országok tovább növelhetik versenyképességüket és logisztikai teljesítményüket. Journal of Economic Literature (JEL) kód: F42, R40, R58.
\end{abstract}

\section{Bevezetés}

A logisztika a legnagyobb ipari ágazat az EU-ban: ezer milliárd euró bevételt hoz létre, és több mint hétmillió európai számára biztosít munkát. ${ }^{1}$ Ezek az adatok jól jelzik e terület jelentőségét a gazdasági teljesítményben. A globalizációval egyre bővülö piac igényeinek kielégítésében nagy szerepet játszik a szervezett szállítás, elosztás, árukövetés és raktározás. A fejlődés - elsősorban a digitalizációnak köszönhetően folyamatosan gyorsul. Az élet mind több területén alkalmazott informatika a modern logisztikában is nélkülözhetetlen: elsősorban az ellátási lánc szervezésében, a készlet-

\footnotetext{
${ }^{1}$ European Logistics Platform, 2020. http://www.european-logistics-platform.eu/\#: :text=In\%20 fact $\% 2$ C\%20logistics\%20is\%20the,Europeans\%20in\%20all\%20European\%20industries.

Tóth Arnold egyetemi docens, Budapesti Gazdasági Egyetem Pénzügyi és Számviteli Kar (e-mail: toth. arnold@uni-bge.hu).

Kálmán Botond egyetemi hallgató, Eötvös Loránd Tudományegyetem Állam- és Jogtudományi Kar (e-mail: kalmanbotond@student.elte.hu).

A kézirat első változata 2020. február 2-án érkezett szerkesztőségünkbe.

DOI: http://dx.doi.org/10.18414/KSZ.2020.11.1154
} 
gazdálkodásban és a szállítási folyamatokban jut kulcsszerephez. A jövőben a digitális tudatosság fontossága a gazdaság minden területén nyilvánvaló lesz, a vezetéstől a munkahelyi környezet kialakításán át a logisztikáig. Ugyancsak a gyorsuló fejlődés következtében a fokozódó környezettudatosság és a határidők gyorsuló rövidülése miatt - az ellátási lánc jellemzőin kívül - egyre újabb területek kerülnek a vizsgálatok középpontjába. A megfelelö logisztikai teljesítmény elengedhetetlen a gazdasági növekedéshez. Bár az ilyen jellegű szolgáltatásokat jellemzően vállalkozások nyújtják, a szabályozás révén a nemzeti kormányok, valamint a regionális és nemzetközi szervezetek is meghatározó szerephez jutnak. A logisztika fontosságának felismerése az utóbbi évtizedekben történt meg.

A logisztikai tevékenységet meghatározza a stratégiai-üzleti szemlélet, ami azt jelenti, hogy a költségek vizsgálatán kívül, azok esetleges növekedése ellenére is, a fö cél a jobb teljesítmény és a fogyasztói elégedettség. E cél elérésére jöttek létre a kifejezetten logisztikai tevékenységet végző szolgáltatók, amelyek a gyártóknál költséghatékonyabban és magasabb minőségben képesek az ügyfelek igényeit kielégíteni. A további fejlődéshez országos szinten is szükségessé válik a logisztikai stratégia és a szabályozás hatékony összehangolása, ami fontos eleme a kormányzati politikának is. Az országok közötti együttmüködés megteremtése szintén a versenyképességet növelö tényező.

Noha a logisztika hozzájárulása egy ország GDP-jéhez nem feltétlenül akkora, mint más versenyképes ágazatoké, a többi gazdasági tevékenység támogatásában játszott szerepét nem szabad figyelmen kívül hagyni. A közlekedés és a logisztika, valamint a nemzeti fejlődés közötti jól ismert kapcsolat megfelelő körülmények között számos más kedvezö gazdasági és társadalmi eredményt hoz. Az ágazat lehetővé teszi a cégek számára, hogy az áruk és szolgáltatások, valamint a kapcsolódó tranzakciók kivitelezését hatékonyan végezzék. A nem megfelelő hatékonyságú logisztika növeli a kereskedelem költségeit, és csökkenti az integráció lehetőségeit. Nemcsak az infrastruktúrát kell azonban fejleszteni, hanem a versenyképesség új tényezőit is, mint például az információáramlás, a telekommunikációs rendszerek, az innovációs módszerek hatékonysága és az új ismeretek gyakorlati alkalmazása. Így a logisztika szerepe növekszik a régió gazdasági versenyképességének javításában.

A hatékony és versenyképes logisztika elemei hozzájárulnak az európai gazdasági növekedéshez. Az ágazat az európai versenyképesség egyik fő mozgatórugója és pillére, megteremtve az utat az áruk mozgásához és a vállalatok közötti együttmüködéshez. A további fejlődés érdekében célszerü tehát összehangolni az erre vonatkozó nemzeti stratégiákat is.

\section{A logisztika szerepe a versenyképesség tényezői között}

A versenyképesség napjainkban a közgazdasági szakirodalom egyik leggyakrabban használt fogalma. Egységes definíciója azonban jelenleg sincs. Ennek az is oka, hogy több szinten is értelmezik: vállalati, regionális és országos szinten, amelyeket különböző mutatókkal jellemeznek (Siudek-Zawojska [2014]). A legmagasabb makroszintű 
jellemzők egyike a Világgazdasági Fórum (World Economic Forum, WEF) által kidolgozott és évente közzétett versenyképességi rangsor alapjául szolgáló, 12 pillérrel leírható globális versenyképességi index (Global Competitiveness Index, GCI - lásd Schwab [2007-2019]). Természetesen a kompetitív magatartás és annak alkotóelemei más módon is értékelhetők. Jelen munkában a logisztikát választottuk célterületként, amelynek napjainkban az egyik legelfogadottabb állapotjelzője a Világbank által 2007 óta általában kétévente közzétett logisztikai teljesítményindex (Logistic Performance Index, LPI - lásd Arvis és szerzőtársai [2007-2018]).

A GCI kompozitindex 12 pillérrel jellemzi az egyes országok versenyképességét. Többek között olyan szempontokat vizsgál, mint az intézményrendszer, az infrastruktúra, az oktatás, az egészségügy, a kutatás-fejlesztés vagy az innováció. A pillérek további alpillérekböl épülnek fel adott módszerrel meghatározott súlyozás alapján, $s$ a végeredmény egy 1-7 skálán kapott szám. Ennek alapján épül fel a vizsgált országok rangsora. Az alpillérek egy része ténylegesen mérhető vagy statisztikailag számszerüsíthető adat, más összetevőket kérdőíves felméréssel határoznak meg a jelentés összeállítói. A kérdőíveket elsősorban üzletembereknek küldik ki a vizsgált országokban. A GCI-t az elmúlt évek során számos kritika érte - főleg a kérdőíves módszer szubjektivitása miatt, különösen azért, mert nem gazdasági kérdésekben is üzletemberek véleményét tekintik irányadónak. A GCI indexstruktúrája 2017-től megváltozott, ezzel kiküszöbölve a kritikákban említett negatívumokat. Az átalakítás fő oka az ipar 4.0-hoz való alkalmazkodás igénye volt. A változtatás számos előnnyel szolgált az indexre nézve, mivel nőtt a statisztikai adatokra alapozott mutatók száma, és egyszerűsödött az egyes pilléreken belül az azok értékét kialakító elemek súlyozása. Korszerüsödött a tartalmi relevancia is, például az egyes pillérek szerepét a versenyképességben a szubjektív, kérdőíves megítélés helyett inkább statisztikai adattal méri a Világgazdasági Fórum.

Az országok logisztikai teljesítményét mérő LPI is pillérekből épül fel. Az országok összehasonlítására alkalmas nemzetközi teljesítményindex mellett nemzeti részt is tartalmaz, amely kiegészíti az egyes országokról alkotott képet. A logisztikai teljesítményindex készítői szintén használnak online kérdőíves felmérést. Alacsony, közepes és magas jövedelmü, tengerparttal rendelkező, illetve szárazföldi országokból egyaránt vannak válaszadók, akik ötfokú Likert-skálán válaszolnak az egyes pillérekben feltett kérdésekre. A válaszokat az index összeállítói átlagolással és előre meghatározott súlyozással dolgozzák fel, végeredményként egy 1-5 skálán mozgó értéket kapnak, ami alapján rangsorolják a vizsgált országokat. Érdekes módon szubjektív jellege miatt a logisztikai teljesítményindexet nem érték negatív kritikák. Ez valószínủleg annak köszönhetö, hogy a kérdőívet a témában illetékes szakemberek töltik ki, akiknek a véleménye szakszerübb.

Mivel a logisztika része a versenyképességnek, több szerző is igazolta a két mutató közötti összefüggést (Çemberci és szerzötársai [2015], D’Aleo-Sergi [2017]). A logisztikai ágazat versenyképességét számos tényező befolyásolja, például a kormányzati politika, a rendelkezésre álló infrastruktúra, az emberi tőke vagy a kamatráták. A versenyképesség fokozása azonban Porter [1998] elméletét követve alapvetően két módon lehetséges: költségalapú vagy termékalapú megközelítéssel. A költségek 
csökkentésére jöttek létre a logisztikai szolgáltatók, amelyek nem foglalkoznak a gyártási és termékfejlesztési folyamatokkal, viszont kiterjedt szállító- és elosztóhálózataik, valamint professzionális szervezőmunkájuk révén tehermentesítik ezek alól a tevékenységek alól a gyártókat. A szolgáltatók is növelhetik a versenyképességüket a Porter-féle megközelítés alapján, fejleszthető termékük a szolgáltatásuk. A hatékonyan müködő logisztikai szolgáltatók képesek jól kihasználni a hagyományos versenyelőnyöket, így a szolgáltatás minőségét, az ügyfélorientált szemléletet, a hatékony marketinget és a reklámozást (Mukhitdinova-Yuldasheva [2020]). Gaudenzi és szerzötársai [2020], valamint Aburayya és szerzötársai [2020] tanulmánya ezek közül az ügyfélelégedettségre helyezi a hangsúlyt. A jobb logisztikai teljesítmény még makrogazdasági szinten is kifejti hatását, a külföldi tőkebefektetők számára elsősorban az infrastrukturális háttér miatt vonzó. A külföldi müködőtőke pedig az egyik fontos motorja a gazdasági növekedésnek. Jelentősége ellenére a logisztikai teljesítmény mérésére ma sincs uinverzális, a logisztika dinamikus jellegét is figyelembe vevő eljárás (Arshinina-Kiseleva [2020]).

Az országos logisztikai versenyképesség összetevőit hat pillérben összegzi a logisztikai teljesítményindex: 1. infrastruktúra (infrastructure), 2. vámok (customs), 3. logisztikai minőség és kompetencia (logistics quality and competence), 4. nemzetközi szállítás (international shipments), 5 . helymeghatározás és nyomon követés (tracking and tracing), 6. idöbeliség (timeliness).

Versenyképességről lévén szó, adódik a gondolat, hogy összevessük az LPI-t és a GCI-t, valamint megvizsgáljuk a kettö közötti kapcsolatot. A két indexben közös, hogy az általuk mért tényezők (a versenyképesség és a logisztikai teljesítmény) közvetlen meghatározói a nemzeti jövedelemnek (GDP). Çemberci és szerzőtársai [2015] szerint a versenyképesség növekedése egyrészt közvetlenül, másrészt a logisztikai teljesítmény javítása révén növeli a GDP-t. Eredményeik szerint a versenyképesség javulása pozitív hatással van a logisztikai teljesítményre. A versenyképesség teljes (közvetlen plusz közvetett) hatása még határozottabb (D’Aleo-Sergi [2017]). A két index közötti korreláció szorosságáról számol be tanulmányában Zekić és szerzőtársai [2017]. Külön elemezték a GCI által mért három fejlettségi klasztert: a tényezö-, a hatékonyság- és az innovációvezérelt gazdaságokat, és mindhárom esetben szoros korrelációt tapasztaltak az LPI és a GCI között. A szerzök kimutatták, hogy a legkevésbé fejlett klaszterbe tartozó országok logisztikai költségei a fejlett klaszterhez képest kétszeresek - ennek okaként az infrastrukturális lemaradást, elsősorban a közlekedés-szállítás fejletlenségét nevezik meg. Eredményeik szerint a tényezővezérelt gazdaságoknak a makrologisztikára, míg a hatékonyságvezérelt gazdaságoknak a mikrologisztikai rendszer fejlesztésére kell összpontosítaniuk. Az innovációvezérelt gazdaságoknak pedig az információs infrastruktúrába és a kommunikációs technológiákba kell befektetniük, és kedvezőbb körülményeket kell teremteni a vállalkozói szellem és az innováció fejlesztéséhez.

Silva [2019] is kimutatta a GCI és az LPI közötti szignifikáns korrelációt Brazília esetében, megállapítva, hogy az ország logisztikai teljesítményében jelentős szerepe van az infrastruktúrának, ami viszont szoros kapcsolatban áll a globális versenyképességgel is. Egy speciális területtel, a férfi és női munkaerö arányának vizsgálatával foglalkozik 
Kisperska-Moroń [2020]. Eredményei szerint a nők aránya a logisztikai szektorban 13-31 százalék közötti, két visegrádi országot konkrétan is említ: Csehországban 26 százalék, Lengyelországban pedig 20 százalék a női dolgozók részvétele a komplett logisztikai láncban. Megállapítja továbbá, hogy ezen a területen a nők bármilyen feladat ellátására alkalmasak az operátori pozíciótól a vezetői beosztásig. Elörejutásuk csak végzettségükön és karrierrel kapcsolatos ambíciójukon múlik.

Ekici és szerzőtársai [2016] részletesen vizsgálta a két kompozitindex kapcsolatát és Törökország logisztikai előrelépési lehetőségeit. Eredményei szerint a logisztikai fejlődés kulcsa az információtechnológiai szektor. Az informatikai fejlettség fontosságát emeli ki Shamsuzzoha és szerzőtársai [2013] elsősorban a logisztika nyomkövetési funkcióit elemző tanulmánya is. A technológiafejlesztés mindig tőkeigényes, ezért fontos a külföldi müködőtőke bevonása. A külföldi müködőtőke és a logisztikai teljesítmény közötti kapcsolatot statisztikailag is igazolta Luttermann és szerzötársai [2020]. Pupavac-Golubović [2015] statisztikai módszerekkel vizsgálta az LPI és a GCI kapcsolatát. A tanulmányban számolt lineáris regresszió szoros kapcsolatot tükröz $[R=0,943, F(1,19)=153,02, p<0,01]$. Ekici és szerzőtársai [2016] mesterséges neurális hálózattal azt vizsgálta, hogy az LPI egyes pilléreihez a GCI melyik alpillére kapcsolódik, meghatározva ezzel az LPI alakulását.

Különösen fontos eleme a korszerű logisztikának a transzport- és telekommunikációs infrastruktúra. Moroza-Jurgelane-Kaldava [2020] a szakirodalom áttekintése alapján fontossági sorrendet állított fel a logisztika tényezöi között. Eredménye szerint a három legfontosabb terület a szolgáltatás színvonala, a költségek és a szállítási hálózat fejlettsége. További lényeges tényezőként említi még a technológiai hátteret, a politikai döntések logisztikai hatásait, az időfaktort és a piacméretet. Mindezek a tényezők felértékelődtek 2020-ban, a mikor a COVID-19-cel kapcsolatos prevenciós szabályok jelentős mértékben megnövelték a házhoz szállítás részesedését a vásárlási formák között (Choi [2020]).

A megfelelő infrastrukturális háttér kialakításában jelentős szerepe van az állami döntéshozatalnak és finanszírozásnak, ami képes a megfelelő irányba terelni a logisztika fejlődését a szélesebb összefüggések átlátása révén (lásd például a „zöldlogisztika” kérdéskörét - Liu és szerzötársai [2020]). Minden állam, függetlenül méretétől, lakosságának számától, a nemzetgazdaság és a foglalkoztatás iránti elkötelezettség érdekében jelentős erőforrásokat fordít a logisztikai fejlesztésekre (Ab Talib és szerzőtársai [2020]). A nemzetközi szállítás hatékonysága a logisztika egyik legfontosabb teljesítménymérője, számos tanulmány foglalkozik az egyes szállítási módok vizsgálatával (Ryguła és szerzötársai [2020], Lin-Hong [2020], Arshinina-Kiseleva [2020]).

\section{A logisztika a visegrádi országok szempontjából}

Az Európai Unióhoz való csatlakozás hatásait hasonlította össze MolendowskiŻmuda [2013]. Korábban Borish-Noêl [1997] az országcsoportban zajló privatizációs folyamatokat elemezte, később Dorożyński-Kuna-Marszałek [2015], valamint Törös és szerzötársai [2016] pedig a visegrádi országok befektetéseket vonzó hatását. Veres 
(szerk.) [2015] átfogó logisztikai stratégiai elemzést nyújtott a visegrádi országokról, amely elsősorban a közlekedési-szállítási infrastruktúrára helyezte a hangsúlyt, kiegészítve az országspecifikus adatokkal. A visegrádi országok átlagához képest Csehországot és Lengyelországot kedvezőbb, Magyarországot többségében átlagos, Szlovákiát inkább az átlag alatti adatok jellemzik. A kötet szerzői javaslatokat tesznek a kooperációra is. Elsősorban a közlekedési infrastruktúra közös kiépítését kezdeményezik a transzportfolyosók mentén, és a nagy sebességü szállítási módok fejlesztését. A közös szabványosítást és a lengyel tengeri kikötők logisztikai szintjének növelését további lehetőségként említik. Kiemelik a közös politikai akarat jelentőségét a logisztikai elörelépés elérésében.

A visegrádi országok logisztikai teljesítményét szintén öt éve vizsgálta utoljára Kramar és szerzőtársai [2015]. Megállapításai összhangban állnak a nemzetközi szakirodaloméval: a logisztika és a versenyképesség között kölcsönös pozitív kapcsolat van. Włodarczyk-Mesjasz-Lech [2019] a visegrádi országok logisztikai elemzésében hívta fel a figyelmet arra, hogy a környezetkárosító közúti szállítási módok túl nagy arányúak, és javasolta a vasúti és belvízi szállítást, illetve a közlekedési infrastruktúra fejlesztésébe való befektetést. Mivel az infrastruktúra fejlesztése költségigényes, Hannola (szerk.) [2013] háromféle lehetséges forrást említ: a lakossági, a kormányzati, valamint a részvénypiaci finanszírozást.

Az említett tanulmányok publikálása óta eltelt öt év alatti geopolitikai változások és azok lecsapódása a logisztikai teljesítménybeli és a versenyképességi jelentésekben indokolttá tette a visegrádi országokra vonatkozó, új szempontokat is figyelembe vevő vizsgálat elvégzését az aktuális adatok felhasználásával. Tanulmányunk ezt a célt szolgálja.

\section{Felhasznált adatok és módszerek}

Munkánk során vizsgálatunkat két nyilvánosan elérhető adatforrásra alapoztuk. Az egyik a Világgazdasági Fórum által kidolgozott és évente közzétett versenyképességi jelentés Schwab (szerk.) [2007-2019] és a benne található globális versenyképességi index (GCI). Ezekből a jelentésekből az adatokat a 2007-2018 közötti időszakból gyüjtöttük össze. Másik forrásunk a Világbank által kidolgozott logisztikai teljesítményindex (LPI), amelyröl 2007 óta átlagosan kétévente készül jelentés. Az index számszerüen értékeli és rangsorolja a logisztikai teljesítményt, segítve a kormányzati vezetőket, a kulcsfontosságú politikai döntéshozókat és a magánszektort abban, hogy megértsék azokat a kihívásokat, amelyekkel ők és kereskedelmi partnereik szembesülnek. Lehetővé teszi a kormányzati és üzleti vezetők számára, hogy jobban felmérjék a hatékony logisztika által biztosított versenyelőnyöket, és megértsék a különféle gazdaságpolitikai tényezők logisztikára kifejtett jelentőségét. Ez a mutató a bevezetésben említett hat elemével jellemzi az országok logisztikai teljesítményét. A hatból három bemeneti változó (infrastruktúra, vámok, szolgáltatások minősége), amelyek meghatározzák a teljesítményt, a másik három kimeneti változó (nemzetközi szállítás, időfaktor, szállítmányok nyomon követhetősége) pedig jellemzi azt. Ebböl az 
adatsorból ugyancsak a 2007-2018 között közzétett értékeket használtuk (Arvis és szerzőtársai [2007-2018]). Mivel a Világbank jelentése 2018-ban jelent meg legutóbb, ezért a GCI-t is csak ezzel az évvel bezárólag vizsgáltuk. Felhasználtunk továbbá frissebb kiadású eredményeket is a jelenlegi állapot értékeléséhez, például a Világgazdasági Fórum 2018 után közzétett globális versenyképességi jelentését is (Schwab szerk. [2019]). Ezeket részben a megváltozott metodika miatt, részben pedig amiatt, hogy 2018 óta még nem jelent meg újabb logisztikai teljesítményindex, idősoros elemzéseinkbe nem vontuk be. A fenti kompozitindexek mellett egyéb mutatók bevonására is szükség volt bizonyos kérdések megválaszolásához. Ilyen például a Világbank Doing Business indexe (WB-DBI), amelynek idősora 2003-ig visszamenően elérhető a Világbank honlapján. ${ }^{2}$

Az LPI és a GCI kapcsolatának elemzéséhez felhasználtuk a Világgazdasági Fórum és a Világbank nyilvános adatbázisait, továbbá az Ekici és szerzőtársai [2016] által közölt megfeleltetési adatokat is. A két kompozitindex alkotóelemeinek viszonyát regressziós vizsgálattal mértük fel. Függő változóként az LPI egy-egy pillérét, független változóként a GCI-nek a függő változóhoz tartozó alpilléreit vizsgáltuk. A vizsgálatba bevontuk mindazokat az országokat, amelyek mind a globális versenyképességi index, mind a logisztikai teljesítményindex rangsorában szerepelnek. A kiugró értékeket külön elemeztük, és az ilyen országokat - például Venezuelát - a további vizsgálatból kizártuk. A normalitást a mintaméret miatt nem vizsgáltuk külön, hivatkozva a centrális határeloszlás tételére. A homoszkedaszticitásra tekintettel a nem megfelelő változókat a lépésenkénti (stepwise) módszert alkalmazva kihagytuk. A varianciainflációs tényező (Variance Inflator Factor, VIF) értéke így mindenütt 7 alatti, tehát a megmaradt változók esetében nem kell jelentős multikollinearitásra számítanunk. A teljesítmény növelésére tett javaslatokat egyrészt a visegrádi országokra kapott eredmények, másrészt a nyugat-európai országok átlagával történt összehasonlítás alapján alkottuk meg. Ezt az átlagot Nyugat-Európa országai GCI-értékeinek átlagaiból számoltuk, súlyozva az egyes országok népességének az össznépességhez viszonyított százalékos részarányával. Javaslattételünkhöz felhasználtuk a regressziós modellben számított elaszticitási mutatót is. Bár a hagyományos értelmezés szerint az elaszticitást mindig pozitív számként (abszolút érték) alkalmazzák, mi most meghagytuk a negatív előjeleket, mivel ezek a két ismérv ellentétes irányú mozgását jelzik.

\section{Eredmények}

Az eredmények ismertetését a logisztikai teljesítményindex összetevői alapján tekintjük át, a bemenő pillérekkel kezdve. Első lépésben azt vizsgáltuk meg, hogy a logisztikai teljesítményindex egyes pillérei szerint a globális versenyképességi index melyik alpillérében teljesítenek gyengén a visegrádi országok. Eredményeinket a magyar adatok bemutatásával szemléltetjük (1. ábra), de mindegyik vizsgált országban hasonló tendenciát figyelhetünk meg.

\footnotetext{
${ }^{2}$ https://www.doingbusiness.org/en/data (World Bank [2020]).
} 
1. ábra

Magyarország GCI-alpilléreinek alakulása a logisztikai teljesítményindex infrastruktúrapillérében

A nyugat-európai átlagtól való

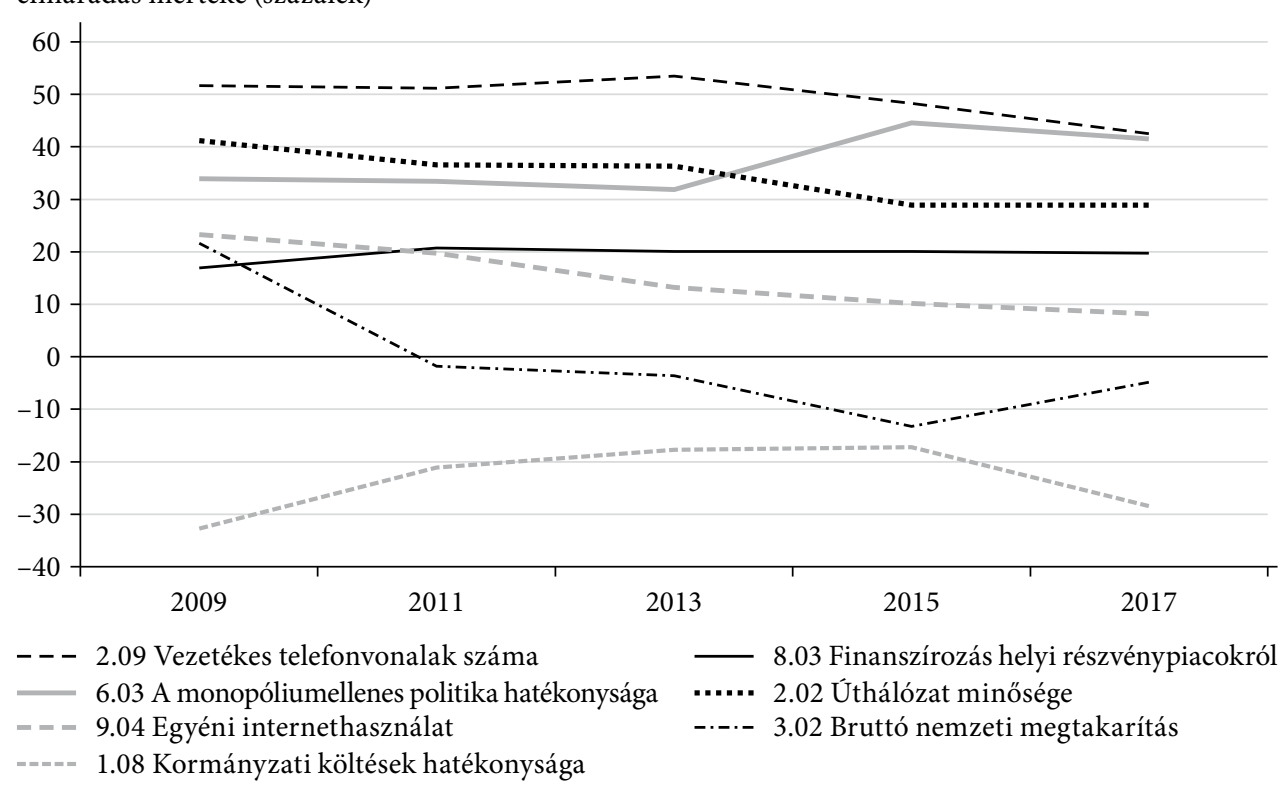

Megjegyzés: a jelmagyarázatban a számok a GCI-mutató kódját jelölik.

Forrás: World Bank [2007-2018] és WEF [2007-2017] adatai alapján saját szerkesztés.

2009 óta valamennyi visegrádi országban az infrastruktúrában a vezetékes telefonhálózat (GCI 2.09) fejlesztése szorult leginkább háttérbe - a mobiltelefonok széles körü elterjedtsége és az internet-hozzáférés mind a vezetékes telefont, mind a faxot szinte feleslegessé tette. Fejlesztésre váró terület az úthálózat minőségének javítása (GCI 2.02). Magyarországon két fontos területen mutatkozik jelentős eltérés a többi vizsgált országtól: 1. a monopóliumok kialakulását és egyeduralkodóvá válását akadályozó politikai döntéshozatal (GCI 6.03), amelynek müködése 2017-ben gyengébb volt, mint 2009-ben, és a 2017-es rangsorban elért helyezés 2020-ig nem változott; 2. a kormányzati finanszírozás (GCI 1.08) a válaszadók véleménye alapján nagyobb hatású, mint a nyugat-európai államokban. Ez a vélemény annak köszönhető, hogy szükséghelyzetekben akár a parlament is dönthet a források átcsoportosításáról. A tökéhez jutás politikától független módja a részvénykibocsátás (GCI 8.03). Ez a terület szintén fejleszthető, hiszen a visegrádi országok lemaradása Nyugat-Európához képest 10-20 százalékos. A finanszírozáshoz kapcsolódó további alpillért is találunk a GCI-ben, amely befolyásolja az LPI infrastrukturális pillérét, ez a bruttó nemzeti megtakarítás a GDP százalékában kifejezve (GCI 3.02). Ez a mutató tulajdonképpen azt mutatja meg, hogy mennyire lehetséges hazai forrásból finanszírozni a beruházásokat, mert ez a fenntartható növekedés egyik kulcskérdése. A visegrádi országok esetében elmondható, hogy mindegyiküknél közel a nyugat-európaival azonos mértékü. 
A 2. ábra a visegrádi országok egymáshoz és Nyugat-Európához viszonyított infrastrukturális teljesítményét mutatja 2009-2017 között. A logisztikai teljesítményindex infrastruktúrapillérében a 2010-es évek közepéig a visegrádi országok közel egyforma fejlödési tendenciát mutattak, 2015-től azonban Magyarország és Szlovákia esetében ez megtörni látszik.

\section{2. ábra}

A visegrádi országok teljesítménye a logisztikai teljesítményindex infrastruktúrapillérében, 2009-2017

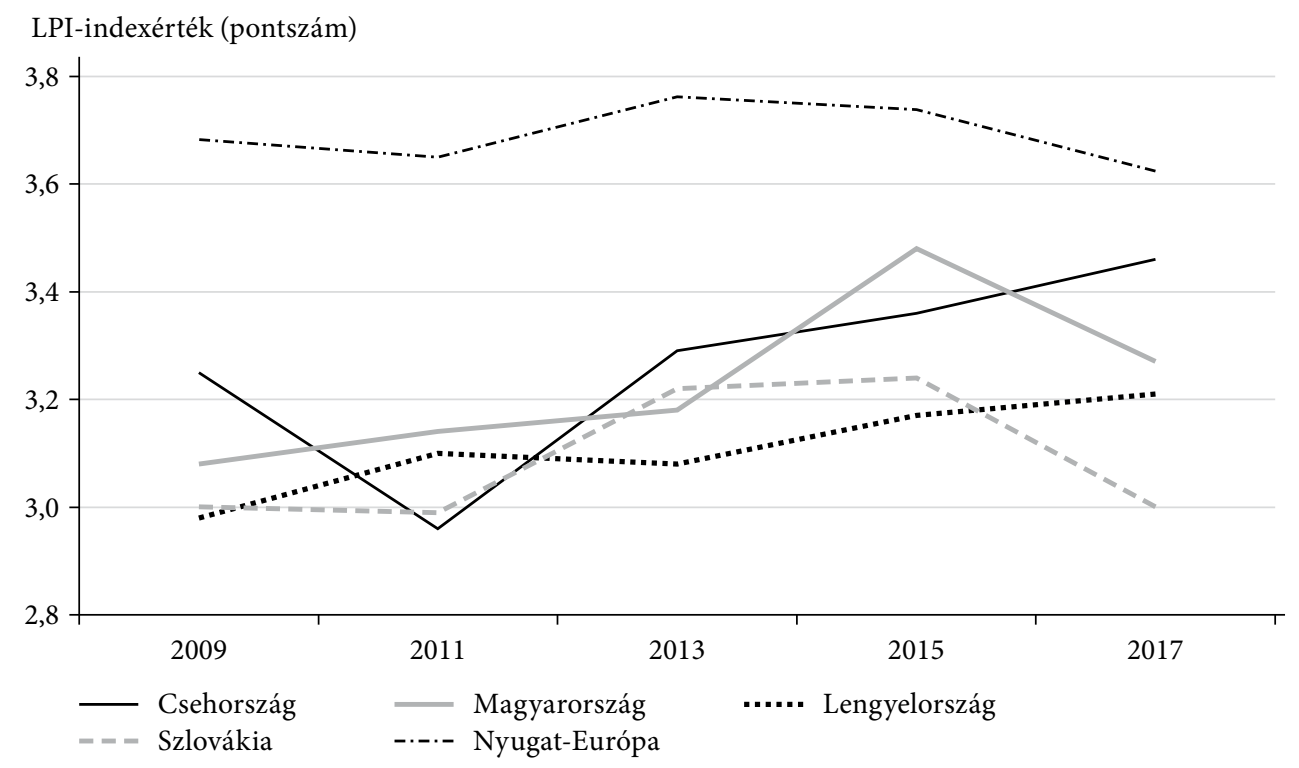

Forrás: World Bank [2007-2018] adatai alapján saját szerkesztés.

Mivel a Világgazdasági Fórum 2018 után jelentősen változtatott metodikáján, az ipar 4.0-kompatibilitás infrastruktúra rangsorában a visegrádi országok a korábbinál sokkal jobb teljesítményt mutatnak. 2017 és 2020 között átlagosan 27 hellyel léptek elörébb a rangsorban, a legnagyobb ugrást Szlovákia produkálta, 33 hellyel javítva rangsorbeli helyét. Különösen pozitív mutató a vasútvonalak sürűsége (új GCI 2.03). Ebben a mutatóban valamennyi visegrádi ország az első 15 helyezett között van, Csehország mutatója a legjobb: a harmadik helyezett a Világgazdasági Fórum 2020. évi rangsorában.

A vámok tekintetében nem meglepő, hogy emelkedésük egyértelmü negatív hatással van a teljesítményre mind a négy visegrádi országban. E negatív hatást elsősorban kormányzati döntéshozatallal és megbízható határrendészeti szolgálatokkal lehet ellensúlyozni. Az LPI vámösszetevőjében jellemzően 3,4-es pontszám alatt teljesítenek a visegrádi országok. A GCI-alpillérek közül a kormányzati döntéshozatal (GCI 1.07) és a határrendészet jelenlegi müködése (GCI 1.16) a döntő elem ezen pontszám kialakulásában, mivel ezek a mutatók 20-40 százalékkal kedvezőtlenebbek a nyugat-európai átlagnál. Maguk a vámok és kereskedelmi díjak (GCI 6.10) csak a harmadik problémaként szerepelnek mind a négy országnál, ugyanakkor a negatív elöjelü értékük jól 
jelzi, hogy növekedésük tovább rontja a logisztikai teljesítményt. Megvizsgáltuk, hogy a Világgazdasági Fórum 2020. évi rangsora alapján tapasztalható-e változás a kormányzati döntéshozatal területén, mivel ez fontos eleme a gazdasági és a logisztikai fejlődésnek. 2017 óta ezen a területen egyik ország rangsorbeli helye sem változott.

A logisztikai teljesítményindex harmadik bemeneti pillére a logisztikai kompetencia. Ezt is számos olyan elem befolyásolja, a melyek a GCI-ben alpillérként szerepelnek. A lista meglehetősen széles körü: monopóliumellenes politika (GCI 6.03), a vevői döntések jellege (GCI 6.16), azaz a vásárlók az olcsóbb ár vagy a jobb teljesítmény alapján választanak-e, a versenyelöny természete (GCI 11.04), az exportpiacok mérete (GCI 10.02) is szerepel itt. A versenyelőny természete terminus némi magyarázatra szorul. A GCI esetében ez azt jelenti, hogy az adott ország a válaszadók szerint miből tud inkább előnyre szert tenni, az eröforrások olcsóságát vagy a termékek és folyamatok egyediségét kihasználva. A visegrádi országok pontszámai alapján megállapítható, hogy a logisztikai teljesítményt ezen a területen elsősorban a vállalkozásindítás folyamatának egyszerüsége és időbeli rövidsége (GCI 6.07) határozza meg. Ebben elsősorban Csehország és Szlovákia mutatott fel jelentős eredményt a vizsgált időszakban (3. ábra). Csehország már 2009-ben sem maradt el a vállalkozásindítás egyszerüségében a nyugat-európai átlagtól, amihez képest a vizsgált időszak végére, 2017-re pedig 15 százalékkal jobb teljesítményt ért el.

\section{3. ábra}

Csehország teljesítménye a logisztikai teljesítményindex kompetenciapillérében

Nyugat-Európához viszonyított teljesítmény (százalék)

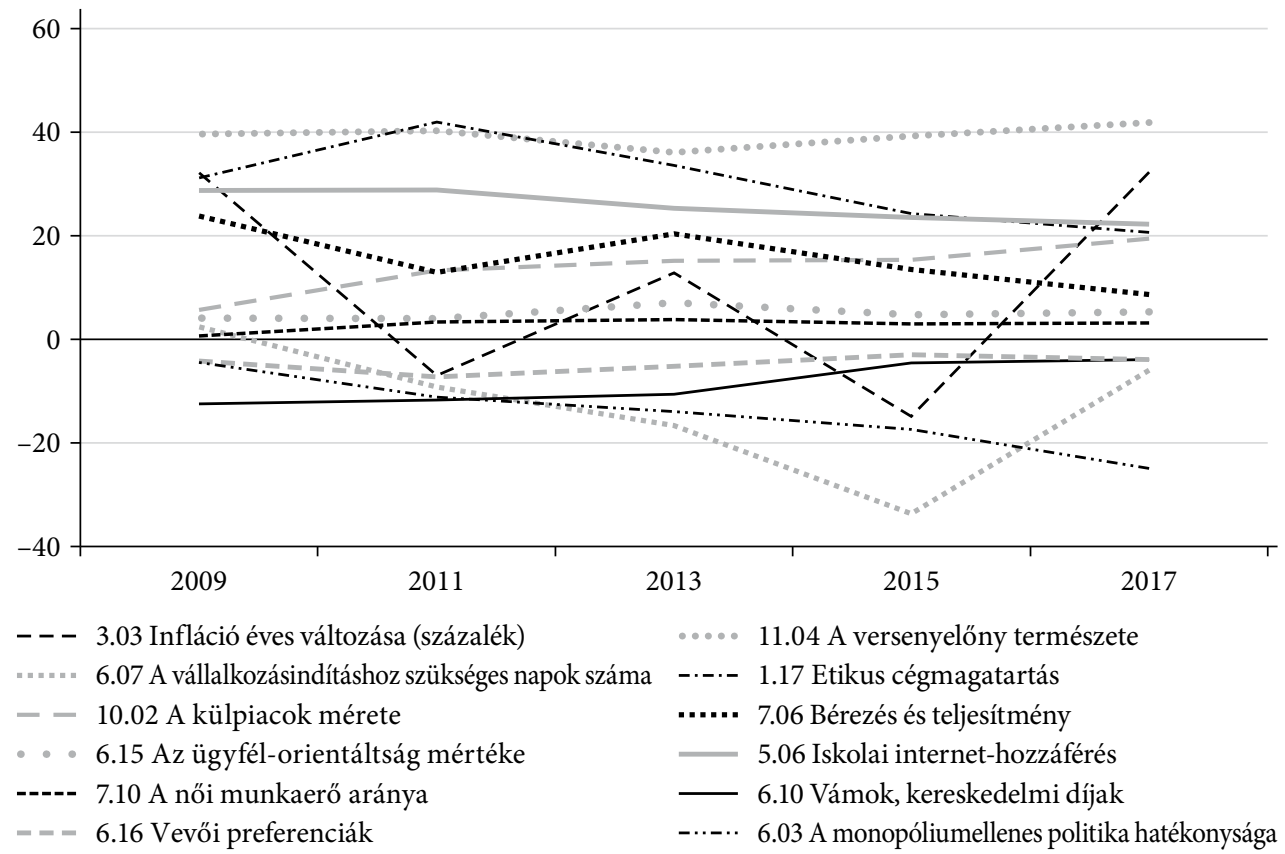

Megjegyzés: a jelmagyarázatban a számok a GCI-mutató kódját jelölik.

Forrás: World Bank [2007-2018] és WEF [2007-2017] adatai alapján saját szerkesztés. 
A 2017-2019 közötti időszak azonban már kedvezőtlenebb képet mutat, mivel a GCI rangsorában Szlovákia két év alatt a 72. helyröl a 114. helyre esett vissza (Schwab [2019]). Lengyelország mutatója nem változott, a magyarországi vállalkozások beindítása viszont kedvezőtlenebbé vált, amit a 2009-2017 közötti 18 százalékpontos csökkenés folytatódása mutat, aminek eredményeként Magyarország Doing Business-indexe a 2017. évi 41. helyröl 2020-ra az 52. helyre esett vissza (World Bank [2020]). Magyarországon eredményeink szerint a legnagyobb lemaradást a nők munkaerőpiaci arányában (GCI 7.10) találtuk, ami érdekes módon a másik három országban is kedvezőtlen mutató, ezt követik az etikus cégmagatartással (GCI 1.17) kapcsolatos problémák és az infláció (GCI 3.03).

A kimenő pillérek közül a nemzetközi szállitás terén közös probléma mind a négy visegrádi országban a versenyelőny természete (GCI 11.04): ezek az országok elsősorban az olcsó munkaerő biztosítása révén „versenyképesek”. Ezt a helyzetet tovább rontja, hogy a vásárlói döntéshozatal (GCI 6.16) alapja az árérzékenység, és nem a termékminőség. A harmadik problémát a külföldi piacok kis mérete (GCI 10.02) jelenti, ezen az összefogás minden bizonnyal javíthat.

A szállítmányok nyomon követése a modern logisztikai rendszerek egyik kulcskérdése (4. ábra).

4. ábra

A visegrádi országok teljesítménye a logisztikai teljesítményindex árukövetés-pillérében

LPI-indexérték (pontszám)

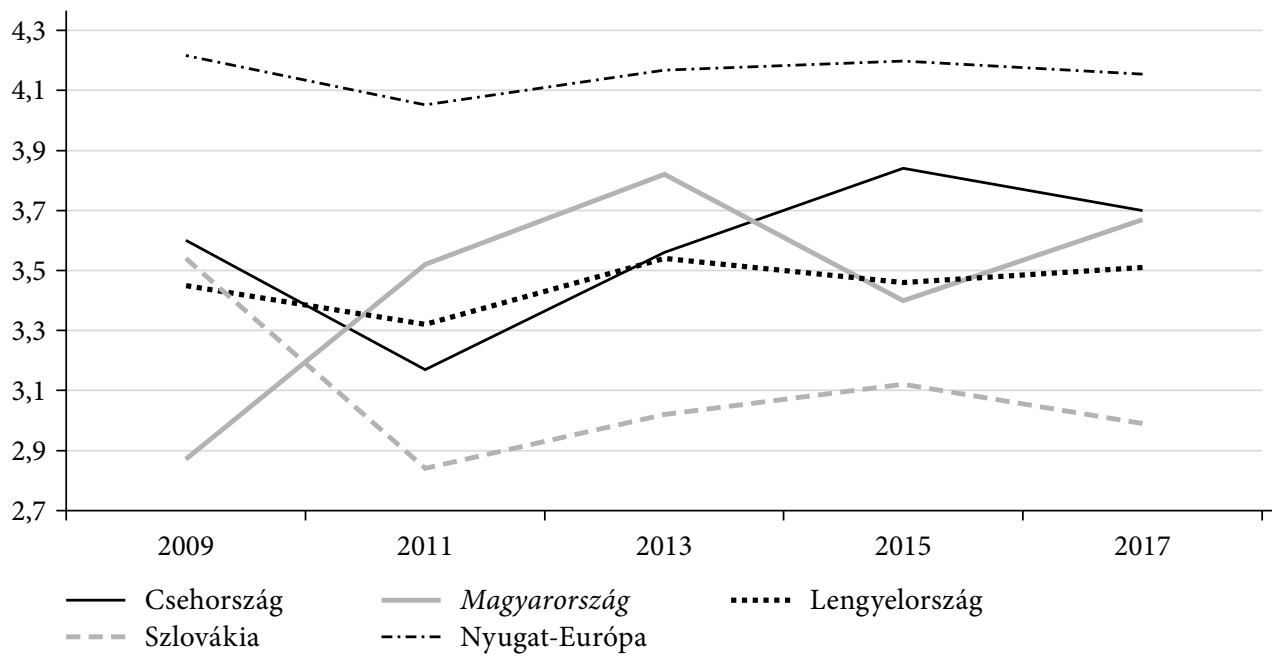

Forrás: World Bank [2007-2018] adatai alapján saját szerkesztés.

Az internet és a helymeghatározás (GPS) technikai fejlődése ma már lehetővé teszi, hogy egy adott küldemény helye percre pontosan követhető és behatárolható legyen. Ezért az infrastruktúra informatikai lemaradása a logisztikai teljesítményindex ezen pillérében is érzékelhető hátrányt okoz. A visegrádi országok mindegyike jelentős, bár egyre kisebb lemaradással küzd e téren a nyugat-európai országokhoz képest. 
Magyarország 2013 óta vezető helyen állt ezen a területen, majd kisebb visszaesés után ismét újra felzárkózva tartja ezt a jó pozíciót. A második javítandó tényező mind a négy országnál - leginkább Magyarország esetében - az értéklánc szélessége (GCI 11.05), ugyanis közös probléma, hogy a vállalatok nagy része csak az értéklánc bizonyos pontjain végzi tevékenységét, és nem fogja át annak teljes egészét. A harmadik fejlesztendő terület: a hazai vállalatoknak nagyobb részt kellene vállalniuk a nemzetközi elosztás (GCI 11.06) és a marketing irányításában.

Az időtényező logisztikai pillérjében a már tárgyalt informatikai lemaradás és az olcsó munkaerő túlsúlya jelenti a legfőbb hátrányt a visegrádi országok számára. Az új technológiák alkalmazásának vállalati szintü bevezetésében (GCI 9.02) már a visegrádi országok is megközelítették a nyugat-európai átlagot. Ellentétben az árukövetéssel, az időpillérben fontosabb szerep jut a külföldi müködőtőkének (GCI 9.03), mint a hazai tulajdonnak, mivel a technikai fejlődés mindig jelentős tőkeigénnyel jár. Ebben a pillérben a visegrádi országok nincsenek lemaradva, valamennyi országnak sikerült megközelítenie a nyugat-európai átlagot.

A második lépésben eredményeinket abból a szempontból elemeztük, hogy melyek azok a GCI-összetevők, amelyeknek fejlesztése a legnagyobb mértékben növeli a logisztikai teljesítményt. Ennek érdekében elaszticitásokat elemeztünk. Az infrastruktúra esetében három mutató (GCI 8.03, GCI 1.08, GCI 3.02) is felhívja a figyelmet arra, hogy a finanszírozás kulcskérdés az infrastruktúra fejlődésében. Elsősorban a hazai részvénypiaci jelenlét a hatékony teljesítményfokozó, de a kormányzati juttatások és a nemzeti megtakarítás is fontos szerepet játszik. Ugyanakkor az is látható, hogy vezetékestelefon-ellátottság (GCI 2.09) és az úthálózat minősége (GCI 2.02) gyakorlatilag nem játszik szerepet a visegrádi országok infrastrukturális fejlődésében. Ennek magyarázata, hogy az infrastrukturális fejlettség az ipar 4.0hoz kapcsolódó logisztikában ma inkább az informatikai színvonaltól függ ott, ahol a megfelelö úthálózat már kiépült. Az informatika viszont tőkeigényes befektetés, ezért ebben az esetben nem mindegy, hogy mekkora tőke áll rendelkezésre, és milyen forrásból. A vámokkal kapcsolatos pillérben eredményeink alapján a rendészeti szervek átlátható müködése (GCI 1.16) és a szakmai alapú kormányzati döntéshozatal (GCI 1.07) fontos elem a logisztika fejlesztésében. Tőkeigényes szektorról lévén szó, a logisztikában a visegrádi országok gazdasági helyzete szükségessé teszi a külföldi tőke bevonását. A tőke pedig leggyakrabban tulajdoni hányadért (GCI 6.11) cserébe érkezik. A kereskedelmi díjak és vámok (GCI 6.10) mindig akadályozzák a szabad logisztikai tevékenységet.

A logisztikai kompetencia terén a legfontosabb, hogy legyen külső piac (GCI 10.02), ahol az ország képes bővíteni a tevékenységét (5. ábra). Ehhez képest kisebb jelentőségü, de fontosságát tekintve mégis meg kell említeni még három tényezőt. Az egyik a politikai támogatás, a kormányzati döntéshozatal monopóliumok kialakulását megakadályozó jellege (GCI 6.03), ami elősegíti a versenyt és a további fejlődést a logisztikában. A másik a cégek oldaláról az ügyfélorientált megközelítés (GCI 6.15).

Ma egy logisztikai cég sikerességének egyik fontos tényezője, hogy ügyfélközpontú szolgáltatást tudjon kínálni megrendelőinek. Fontos szempont még a további fejlödéshez a vállalkozások etikus magatartása (GCI 1.17), a versenyelőny természete 
5. ábra

A logisztikai teljesítményindex kompetenciapillérét befolyásoló rugalmassági mutatók

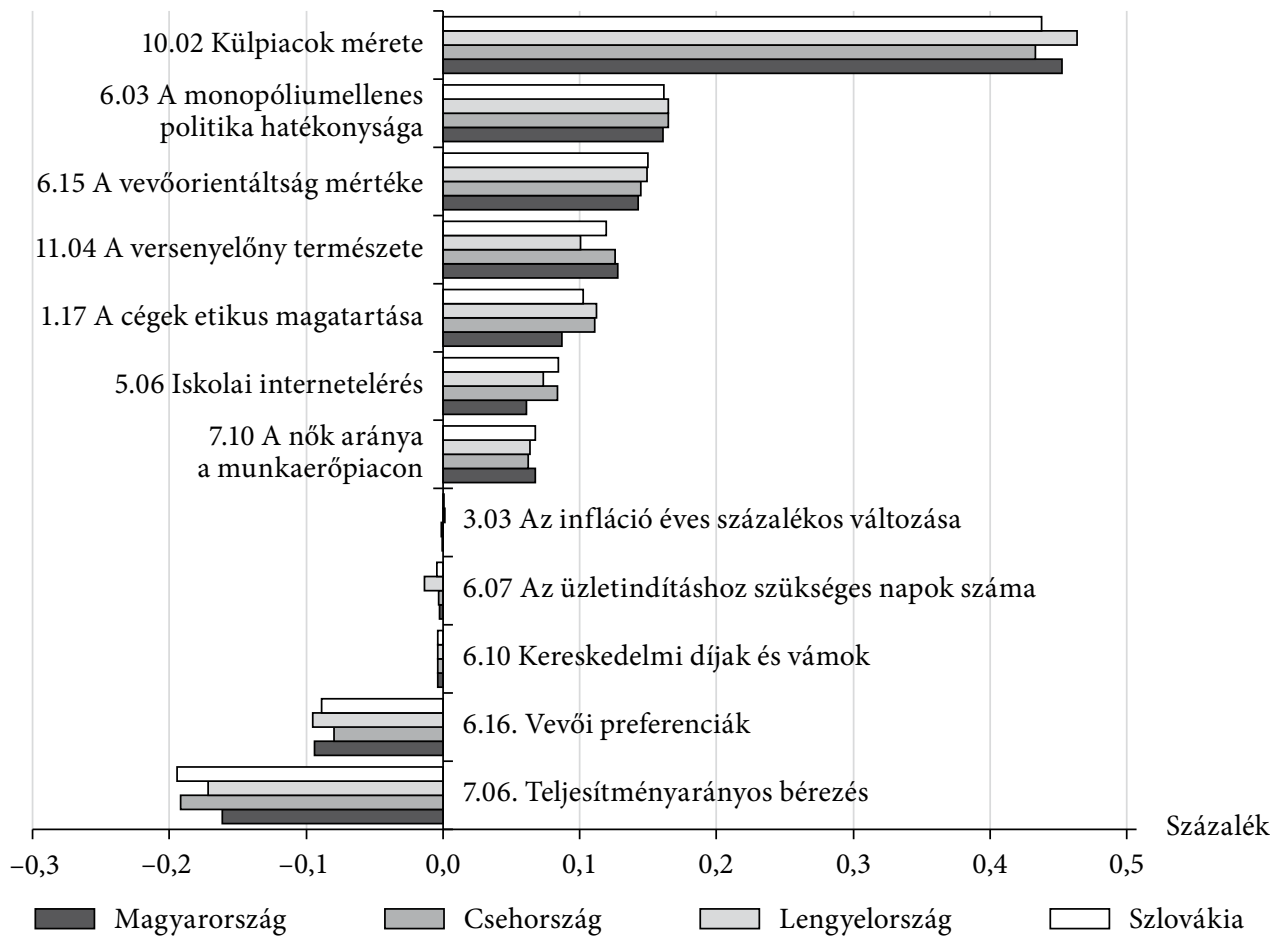

Megjegyzés: a függőleges tengelyen a számok a GCI-mutató kódját jelölik. Az $x$ tengelyen a mutató 1 százalékos változása hatására az LPI-tényező százalékos növekedése szerepel. Forrás: World Bank [2007-2018] és WEF [2007-2017] adatai alapján saját szerkesztés.

(GCI 11.04) és a nők részvételi aránya (GCI 7.10) a logisztikai szektorban. Nem befolyásolja érdemben a logisztikai kompetenciát az infláció (GCI 3.03) és az üzletindítás egyszerüsége (GCI 6.07) vagy bonyolultsága. Negatív hatással van viszont erre a területre a kereskedelmi díjak és vámok (GCI 6.10) változása, s nehezíti a kompetenciákban az elörelépést az is, ha az ügyfelek nem ár-, hanem teljesítményalapú döntéseket hoznak (GCI 6.16). Itt azonban nincs szó korrelációról, és még kevésbé oksági kapcsolatról. Statisztikailag csupán látszólagos együttjárásról van szó, mert a logisztikai vállalkozásoknak az egységnyi előrelépéshez sokkal komolyabb feltételeknek kell megfelelniük, ha az ügyfelek igényei is magasak.

Érdekes probléma, hogy miért hat a teljesítménytől függő bérezés (GCI 7.06) negatívan a logisztikai kompetenciára. Erre választ adhat például az, hogy a teljesítménybérezés elsősorban a beosztottak motiválására alkalmas. A vezetői feladatok professzionális megoldása a logisztikában is gyakran teljes embert kívánó feladat, ezért az állandó rendelkezésre állás miatt megfelelő fix bért, esetleg további juttatásokat kell biztosítani ahhoz, hogy ez a vezetőnek is motiváló tényező legyen. Ezért lehet a teljesítményalapú bérezés a magas szintü logisztikai fejlesztésben negatív tényező. 
Vizsgálatunk eredményei alapján a nemzetközi szállítás teljesítményére legnagyobb mértékben a külső piacok mérete (GCI 10.02) gyakorol hatást. Mivel ez a visegrádi országok esetében a logisztikában vezető helyen álló Németországhoz képest kicsi, növelésében elsősorban az összefogás révén lehet jelentősebb bővítést elérni. A versenyelőny természete (GCI 11.04), azaz az olcsó munkaerőre alapozott versenyképesség terén a tudásintenzív irányba való elörelépés fontos elem lehet a logisztikai teljesítmény fejlesztésében. További piacbővítésre ad lehetőséget a külföldi müködőtőke bevonása (GCI 9.03), ami a már meglévő piacokat növelheti a befektetők országaival. További fejlődési lehetőséget jelent a döntési kompetenciák helyi szintre történő delegálása (GCI 11.09) is. Szerepelnek még a nemzetközi szállítási teljesítmény befolyásolásában a vámok és díjak (GCI 6.10) is, de negatív hatásuk ebben az LPI-pillérben csak minimálisan érvényesül. Negatív a hatása a teljesítményre a vásárlói igényesség (GCI 6.16) fejlődésének, ami ebben az esetben is csak látszólagos negatív korreláció, ami azzal magyarázható, hogy minél igényesebbek a vevők, annál nehezebb megfelelni az általuk elvárt feltételeknek.

Az árukövetésben szereplö GCI-alpillérek mindegyike összhangban van a gyakorlatból és a szakirodalomból ismert következtetésekkel (6. ábra). Annál jobban tud ugyanis teljesíteni az adott ország a logisztikában, minél több pontján vannak jelen saját hazai vállalatai (GCI 11.06) az értékláncban (GCI 11.05), közvetlen ellenőrzésük alatt tartva így a termék teljes életciklusát. A modern követési rendszerek ma már mind informatikaalapúak, ezért az internet folyamatos szélessávú elérése (GCI 9.05) nélkülözhetetlen. A fejlödéshez arra is szükség van, hogy a logisztikai vállalkozások minél hamarabb átvegyék, bevezessék és alkalmazzák a korszerü technológiákat (GCI 9.02). Fontos még a kereskedelmet gátló tényezők (GCI 6.09) felszámolása is.

\section{6. ábra}

A logisztikai teljesítményindex árukövetés-pillérét befolyásoló rugalmassági mutatók

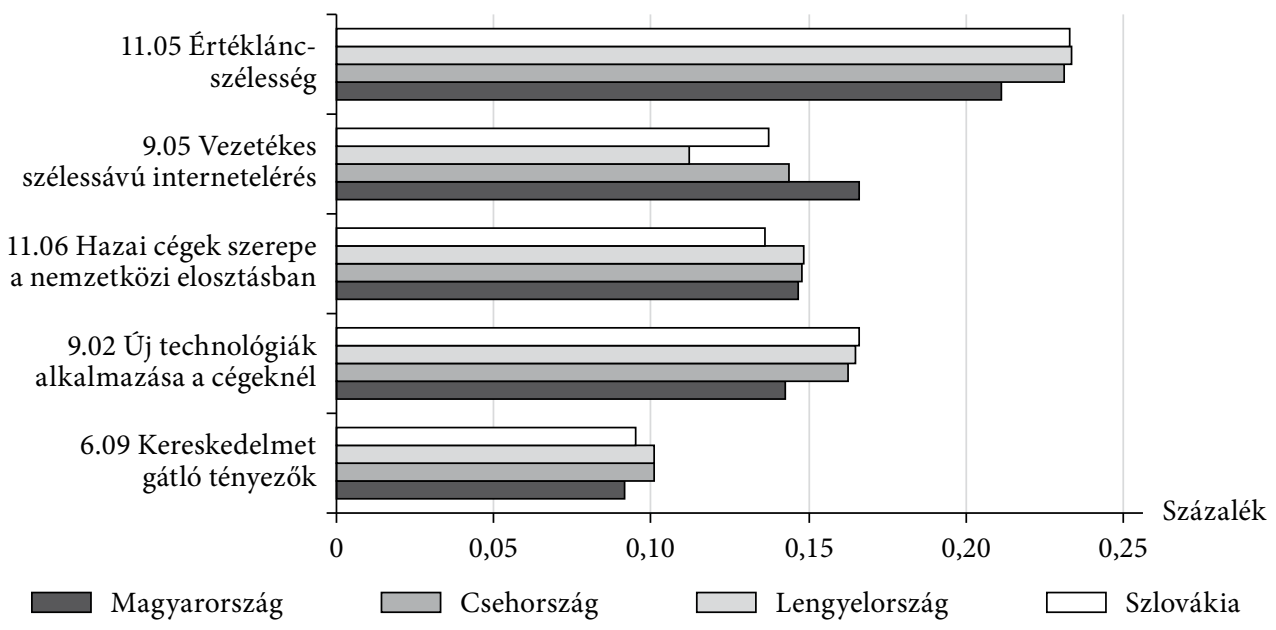

Megjegyzés: a függőleges tengelyen a számok a GCI-mutató kódját jelölik. Az $x$ tengelyen a mutató 1 százalékos változása hatására az LPI-tényező százalékos növekedése szerepel. Forrás: World Bank [2007-2018] és WEF [2007-2017] adatai alapján saját szerkesztés. 
A fejlődés iránya a mobilrendszerek felé tart, ezért megnéztük azt is, hogy hogyan változott 2017 után a mobil szélessávú előfizetések (GCI 9.07, új GCI 3.02) helyzete. Szlovákia helyezése romlott, Csehországé nem változott, a másik két tagállam viszont elörébb lépett ezen a területen. Különösen Lengyelország fejlődése látványos: a 2017es 69. helyről 2020-ra a 3. helyre lépett elő a Világgazdasági Fórum által vizsgált 141 országot tartalmazó rangsorban.

Az időfaktor javításában a visegrádi országoknak mindenképpen szükségük van a külföldi müködőtőke bevonására (GCI 9.03) is (7. ábra). Egyrészt a modern technológia rendszerbe állítása (GCI 9.02), másrészt az informatikai infrastruktúra kiépítése és folyamatos korszerüsítése céljából. Az FDI-igény fö oka az időfaktort befolyásoló következő GCI-alpillér, az olcsó munkaerőn alapuló versenyképesség (GCI 11.04). Olcsó munkaerővel viszont nem lehet megfelelni a befektetői igényeknek, ha drága technika kezelését kell a dolgozóknak elsajátítaniuk. Enyhén negatív hatásúak az időbeliségre a vámok és kereskedelmi díjak (GCI 6.10), és még inkább hátráltatják az időbeliség javulását a szakmai alap nélkül meghozott politikai döntések (GCI 1.09).

\section{7. ábra}

A logisztikai teljesítményindex időtényező-pillérét befolyásoló rugalmassági mutatók

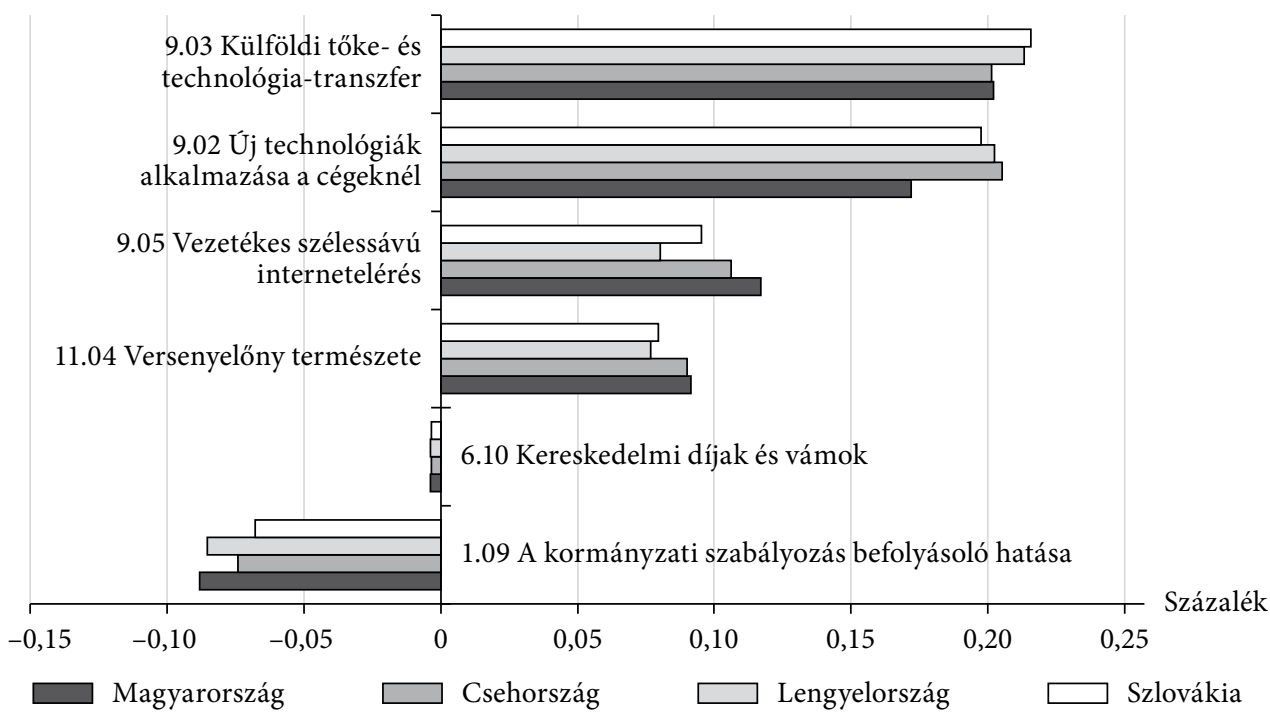

Megjegyzés: a függőleges tengelyen a számok a GCI-mutató kódját jelölik. Az $x$ tengelyen a mutató 1 százalékos változása hatására az LPI-tényezö százalékos növekedése szerepel.

Forrás: World Bank [2007-2018] és WEF [2007-2017] adatai alapján saját szerkesztés.

\section{Összegzés}

A 2017-es adatok alapján a visegrádi országok a logisztikai teljesítményt tekintve a 20-30. helyen álltak a világ országai között, egyedül Szlovákia volt lemaradva az 58. helyen (Arvis és szerzőtársai [2018]). Ugyanezen évi adatok alapján a globális 
versenyképességi rangsorban Csehország és Lengyelország a 30-40. helyen ált, míg Szlovákia és Magyarország tölük közel 30 hellyel lemaradva volt 59-61. helyezett (Schwab [2019]). Ugyanakkor a legutóbbi, a 2019. évi GCI-rangsorban Magyarország a 47., Szlovákia a 42. helyre lépett elöre. Ez egyrészt annak is betudható, hogy az új módszertan a modern ipar 4.0 követelményeket veszi figyelembe, és ezekben ez a két ország jobban teljesít. Különösen jól illusztrálja ezt az a tény, hogy az infrastruktúrapillérben a visegrádi országok mindegyike jelenleg a 20-30. hely között mozog. Az információtechnológiai szektor jelentős fejlödése az infrastruktúrán belül pozitív jövőkép lehetőségét jelzi (ez egybevág Ekici és szerzőtársai [2016] megállapításaival, továbbá Arvis és szerzőtársai [2018] eredményeivel). Szükség van viszont a közlekedési infrastruktúra további fejlesztésére, ebben pedig kulcsfontosságú a kormányzat döntéshozatali és finanszírozási szerepe. A logisztikai teljesítményindex infrastruktúrapillérét meghatározó GCI-mutatók között - Hannola (szerk.) [2013] megállapításával összhangban - hármat is találunk, amelyek a finanszírozással kapcsolatosak. Ezek a visegrádi országokban a következő sorrendben fejtik ki a logisztikai teljesítményre gyakorolt hatásukat: legfontosabb a kormányzati finanszírozás hatékonysága, ezt követi a bruttó nemzeti megtakarítás, majd a részvénypiaci finanszírozás.

A vámok nemzetközi kereskedelemre kifejtett negatív hatása közismert, ezt vizsgálatunk is megerösíti. Ez az a terület, amelyet a visegrádi országok esetén a leggyengébbnek találtunk a logisztikai teljesítményindex pillérei közül, azonban Arvis és szerzőtársai [2018] szerint ez világjelenség: a legfejletlenebbtől a legfejlettebb logisztikájú országokig egyaránt ez a pillér teljesít legrosszabbul.

A logisztikai kompetenciát a visegrádi országok között elsősorban a versenyelöny természete határozza meg, ezekben az országokban elsősorban az olcsó munkaerő biztosítja a versenyképességet, ennek azonban a technológia fejlődése által támasztott, képzett munkaerő iránti növekvő igények miatt egyre kevésbé van jelentősége.

Ugyanakkor a visegrádi országok hatékonyabbak a vállalkozásinditás terén - annak egyszerüsége miatt -, mint a nyugati országok. Ezt igazolja a Világbank Doing Business című kiadványa, amely szerint a vizsgált 190 ország között a legutóbbi felmérésben mind a négy visegrádi ország a felső harmadba került (World Bank [2020]).

A nök logisztikai szektorban való részvételével kapcsolatban visszautalunk Kisperska-Moroń [2020] eredményeire. Saját adataink alapján is elmondható, hogy a 2018. évi logisztikai teljesítményindexek kompetencia-rangsorában Csehország és Lengyelország között kilenc hely különbség mutatkozik, amiben bizonyosan szerepet játszik, hogy a cseh logisztikai vállalkozásokban a nők részvételi aránya hat százalékponttal magasabb, mint a lengyel vállalkozásokban. A női munkaerő a visegrádi országokban - hasonlóan a többi volt szocialista országhoz - az 1990-es évek előtt sokkal magasabb arányú volt, mint Nyugat-Európában, ami a szocialista rendszerek munkaeszményének következménye volt. Mára a nyugati államok is utolérték a visegrádi országokat ezen a téren.

A kimenő pillérek közül a nemzetközi szállításban a teljesítmény fokozásának két közös fékezője a külpiacok kis mérete és az olcsó munkaerőre alapozott versenyképesség, amit a jellemzően árcentrikus fogyasztói szemlélet tovább ront. A külkereskedelmi 
lehetöségek együttes kihasználása és a tudásintenzív tevékenységek nagyobb súlya akár az oktatás közös fejlesztése révén - jelentős logisztikai előrelépést jelenthetne a visegrádi országok számára. Az árukövetésben az informatika színvonalának fontosságát támasztja alá Shamsuzzoha és szerzőtársai [2013] is. Ezért az infrastrukturális - elsősorban az internet-hozzáférés színvonalát érintő - lemaradás csökkentése és a hazai tulajdonú logisztikai vállalkozások arányának növelése hozhat mérhető fejlődést. Látszólag ellentmond az előző állításnak a külföldi működőtőke fontosságának hangsúlyozása, amit alátámaszt Luttermann és szerzötársai [2020], de a technológiaigényes tevékenység mindig jelentős tőkeigénnyel is jár. Az ellentmondás feloldható azzal, hogy a külföldi tőke bevonásának nem kell többségi külföldi tulajdonnal is járnia. Az időbeliség követelményeinek egyre pontosabb teljesítéséhez is szükség van külföldi müködőtőkére, mivel a gyorsaság fokozása technológiafüggő, ezért a cégek csak tőkebefektetéssel képesek lépést tartani a fokozódó igényekkel.

Bár a teljesítményalapú elemzés is számos közös pontot megjelölt a visegrádi országok logisztikájában, még kifejezettebbé vált ezen országok összetartozása a rugalmasságelemzés alapján. A logisztikai teljesítményindex valamennyi pillére esetében mind a négy országban ugyanazokat a GCI-alpilléreket találtuk legrugalmasabbnak. Ez azt jelenti, hogy a visegrádi országoknak ugyanazokat a pilléreket érdemes fejleszteniük, ha a logisztika területén szeretnének az élmezőnyhöz közelebb kerülni. A rugalmasságvizsgálat egyértelmüen igazolta, hogy a logisztika nagy tőke- és informatikaigényű területe a gazdaságnak, amit ki kell egészítenie a képzett és nagy tudásszintű emberi erőforrásnak, de a hatékony müködéshez a politikai döntéshozatali támogatás is nélkülözhetetlen.

Végül, eredményeink korrekt értékelhetősége érdekében meg kell említenünk, hogy a rugalmasságvizsgálatok eredményei alapján önmagában egy GCI-alpillérben elért egyszázalékos javulás csupán ezrelékes vagy még kisebb arányban javít a logisztikai teljesítményen. Ez azonban nem teszi kétségessé a leírt összefüggéseket, ugyanis az LPI és a GCI is kompozitindex. Vizsgálatunkból - ahogyan azt a metodológiai részben említettük - a multikollinearitás elkerülése érdekében több elemet is kizártunk. Ez megkönnyítette az LPI és a GCI közötti összefüggések feltárását, azonban a valóságban a kompozitindexek pillérei sosem függetlenek egymástól, az egyik pillér változásának minden esetben tovagyürüző hatásai is vannak. Ezért nem lehet egyetlen pillérben javított teljesítménnyel a logisztikai hatékonyságot egyértelmüen növelni. Az egyes alpillérek hatása komplex, nemzetgazdasági szinten multiplikatív, ezért az ezrelékes növekedések a gyakorlatban jelentős változást eredményezhetnek.

\section{Ajánlások}

A négy ország logisztikai teljesítménye - a közös múlt és a gazdaság hasonló fejlettségi szintje következtében - hasonló, ezért a gazdasági és a logisztikai fejlödésben is szinte azonos feladatokkal szembesülnek. Elsőrendü tennivalók közé tartozik az infrastruktúra korszerüsítése, igazodva az ipar 4.0 feltételeinek irányvonalához. Ez elsősorban az infrastrukturális szektor és az internetellátottság jelentős átalakítását 
igényli. A klasszikus logisztikai mutatók, például az úthálózat minősége mára már kisebb jelentőségü, mint néhány évvel korábban. Az utak minőségének javításán túl a közúti közlekedési infrastruktúrában elsősorban a vezető nélküli jármüvek, a navigáció és helymeghatározás, valamint a környezetkímélö meghajtási módok várnak fejlesztésre. Példaként említhetjük az elektromos járművek terjedését. Tekintettel a multikollinearitás jelenségére, a közlekedésfejlesztés szervesen kapcsolódik az informatikához és a gyors nagy tömegü adatfeldolgozáshoz (5G-hálózatok).

A fenti fejlödési folyamatban nélkülözhetetlen az állam szerepe, amely mind a politikai döntéshozatal, mind a finanszírozás oldaláról jelentős meghatározója a fejlödésnek. A monopóliumok kialakulását akadályozó szabályozás, a szakmai alapú döntéshozatal és az állami források hatékony felhasználása nélkül egyikállam sem várhat elörelépést sem a gazdasági, sem a logisztikai versenyképességben. Az államnak abban is van szerepe, hogy a visegrádi országok az olcsó munkaerő bázisáról a tudásintenzív versenyképesség irányába fejlődjenek tovább. Ez ugyanis oktatás és képzés nélkül nem valósulhat meg, tehát az államnak az oktatás fejlesztésére is jelentős forrásokat kell szánnia. Az így befektetett tőke a jövőben várhatóan megtérül, és megjelenik a munkaerő értékének, valamint a GDP-nek a növekedésében. Ha a rövid távú gazdaságpolitikai szemlélet miatt ez elmarad, akkor a visegrádi országok már a közeli jövőben behozhatatlan hátrányba kerülhetnek. Ennek kedvezőtlen hatásai pedig sokrétűek lehetnek, például bizonyosan gyengül az országcsoport politikai befolyása is.

Mind az állam, mind a vállalkozások anyagi forrásai jelentősen bővíthetők az uniós források hatékony felhasználásával. Az operatív programokból elnyerhető uniós támogatások kiemelt szerepet töltenek be az ágazat fejlesztésében. A visegrádi országok szerepelnek annak a 15 országból álló csoportnak az élén, amely 2020 februárjában környezetvédelmi célokra fordítható közvetlen uniós forrásokat kért Brüsszeltől, amelyeket - többek között közös konzorciumban megvalósított tenderben - több ezer elektromos autóbusz beszerzésére fordítanának. ${ }^{3}$ A zöldlogisztika fejlesztésében a vasúti szállítási hálózatok összehangolása lehet jelentős tényező, mivel a belvízi szállítások lokalizált megvalósíthatósága, illetve a légi szállítási infrastruktúra különösen tökeigényes fejlesztése kevésbé hatékony alternatívát jelent.

A közös projekteket azoknak az államoknak kell vezetniük, amelyek az adott területen a legjobban teljesítenek. Eredményeink alapján Magyarország az árukövetés, Csehország a nemzetközi szállítás LPI-pillérének fejlesztésében játszhat vezető szerepet. A logisztika területén minden fejlesztés magas tőkeigényü. Ugyanakkor ahhoz, hogy a külföldi működőtőke számára vonzók legyenek, az államoknak maguknak is jelentős erőforrásokat kell erre a célra biztosítaniuk. Jelen fejlettségi szintjük alapján ugyanis mind a külföldi müködőtőke bevonása, mind a külföldi technológia alkalmazása nélkülözhetetlen eleme a versenyképesség és a logisztika magasabb szintre emelésének.

Vannak természetesen az egyes országok számára csak rájuk jellemzö fejlesztésre váró feladatok. Magyarország esetében ilyennek bizonyult a cégek etikus magatartásának javítása. Csehország esetében egyes gazdasági mutatók, Lengyelországban

\footnotetext{
${ }^{3}$ https://adozona.hu/altalanos/Kozvetlenul_elerheto_unios_forrasokat_szere_4LID9S.
} 
a politikai döntéshozatal javítását találtuk említésre méltó tényezőnek, Szlovákia pedig külső piacainak kis méretével küzd. A piacméret növelése ugyanakkor mindegyik visegrádi ország számára fontos feladat. Ez csak összefogással oldható meg. A visegrádi országok közösen szervezhetik külkereskedelmüket, és megoszthatják egymással piacaikat, ami nemcsak a növekedést, de a költséghatékonyságot is fokozza.

Kutatási kérdésünk arra irányult, hogy a visegrádi országcsoport államai mely versenyképességi mutatók fejlesztésével tudják leginkább fokozni logisztikai teljesítményüket. A válasz megtalálása érdekében megvizsgáltuk a Világgazdasági Fórum versenyképességi és a Világbank logisztikai teljesítményindexének idősoros adatait. Elemeztük a két kompozitindex pillérei közötti kapcsolatokat, valamint azt, hogy a versenyképességi pillérek változása milyen irányú és mértékű hatással van a logisztikai teljesítmény egyes összetevőire. A visegrádi országokra vonatkozóan olyan közös, illetve országspecifikus jellemzőket tártunk fel, amelyek fejlesztése növeli a logisztika hatékonyságát.

Minden vizsgált országban a legfontosabb fejlesztendö területek közé tartozik az informatikai infrastruktúra, amely a logisztika modernizációjához ma már elengedhetetlen. Mivel erőforrás-igényes feladatról van szó, fontos a megfelelő mértékủ finanszírozás, amely kormányfeladat, de a részvénypiacok és az külföldi müködőtőke szerepe is számottevő. Hasonlóan fontos mindegyik visegrádi ország számára, hogy versenyképességét a jövőben ne az olcsó, hanem a képzett munkaeröre alapozza.

A számos új technológiát tartalmazó ipar 4.0 jelentősen átalakítja a logisztikai szolgáltatók müködését. Ilyen például a dolgok internete (Internet of Things, IoT), a felhőalapú logisztika, a rádiófrekvenciás technológia (Radio Frequency Identification, $R F I D)$ és a vállalati erőforrás-tervezés (Enterprise Resource Planning, ERP). Szükségessé válik minden művelet digitalizálása a teljes ellátási láncon belül, valamint a fizikai rendszerek integrálása a kibertérrel. A modern logisztika valós idejü adatokat igényel, és dinamikus strukturális szerveződést kíván az ellátási lánc különböző elemei között a költségek, az idő és az erőforrások jobb optimalizálása érdekében. Az ipar 4.0 hatására 2018-tól átalakult az általunk vizsgált globális versenyképességi index teljes indexstruktúrája is. Ezért amennyiben az új adatokkal is hosszabb idősor áll majd rendelkezésre, a jövőben újra kell vizsgálni a GCI-alindexek LPI-re kifejtett hatását is. Az új adatokkal várhatóan új összefüggéseket, illetve árnyaltabb és aktuálisabb képet remélünk a versenyképesség és a logisztika kapcsolatáról.

\section{Hivatkozások}

Aв Talib, M. S.-Pang, L. L.-Ngah, A. H. [2020]: The role of government in promoting Halal logistics: a systematic literature. Journal of Islamic Marketing, július 2. http://dx.doi. org/10.1108/jima-05-2020-0124. 
Aburayya, A.-Marzouqi, A. A.-Alawadhi, D.-Abdouli, F.-Taryam, M. [2020]: An empirical investigation of the effect of employees' customer orientation on customer loyalty through the mediating role of customer satisfaction and service quality. Management Science Letters, 2147-2158. o. http://dx.doi.org/10.5267/j.msl.2020.3.022.

Arshinina, P.-Kiseleva, A. [2020]: Evaluation of the Effectiveness of the Logistics System. International Conference on Economics, Management and Technologies 2020 (ICEMT 2020). Advances in Economics, Business and Management Research, Vol. 13. Atlantis Press, 486-490. o.

Arvis, J.-F. És szerzőtársai [2007-2018]: The Logistics Performance Index and Its Indicators. World Bank, Northwest, https://lpi.worldbank.org/report.

Arvis, J.-F.-Ojala, L.-Wiederer, C.-Shepherd, B.-RaJ, A.-Dairabayeva, K.-KiIski, T. [2018]: Connecting to Compete - Trade Logistics in the Global Economy, 2018. World Bank, Washington, https://openknowledge.worldbank.org/bitstream/handle/10986/29971/ LPI2018.pdf.

BorIsH, M.-NoÊL, M. [1997]: Privatisation in the Visegrad Countries: A Comparative Assessment. The World Economy, Vol. 20. No. 2. 199-220. o. http://dx.doi.org/10.1111/1467-9701.00066.

Çemberci, M.-CiveleK, M. E.-Canbolat, N. [2015]: The Moderator Effect of Global Competitiveness Index on Dimensions of Logistics Performance Index. Procedia - Social and Behavioral Sciences, Vol. 195. 1514-1524. o. https://doi.org/10.1016/j.sbspro.2015.06.453.

Chог, T. M. [2020]: Innovative "bring-service-near-your-home" operations under Coronavirus (COVID-19/SARS-CoV-2) outbreak: Can logistics become the Messiah? Transportation Research, Part E: Logistics and Transportation Review, Vol. 140. https://doi. org/10.1016/j.tre.2020.101961.

D'Aleo, V.-Sergi, B. S. [2017]: Does logistics influence economic growth? The European experience. Management Decision, Vol. 55. No. 8. 1613-1628. o. https://doi.org/10.1108/ md-10-2016-0670.

Dorożyński, T.-Kuna-MarszaŁeK, A. [2015]: Investment Attractiveness of Visegrad Group Countries. Megjelent: Banking, Finance, and Accounting. IGI Global. 41. fejezet, 740-775. o. http://dx.doi.org/10.4018/978-1-4666-6268-1.ch041.

EкICI, Ö. Ş.-KaвAK, Ö.-ÜlengIN, F. [2016]: Linking to compete: Logistics and global competitiveness. Transport Policy, Vol. 48. 117-128. o. http://dx.doi.org/10.1016/j. tranpol.2016.01.015.

GAudenzi, B.-Confente, I.-Russo, I. [2020]: Logistics service quality and customer satisfaction in B2B relationships: a qualitative comparative analysis approach. The TQM Journal (ahead-of-print), https://doi.org/10.1108/tqm-04-2020-0088.

Hannola, L. (szerk.) [2013]: Guidebook to Financing Infrastructure for Transport and Logistics within Northern Dimension. Research Reports/LUT Scientific and Expertise Publications, Lappeenranta, https:/lutpub.lut.fi/bitstream/handle/10024/90347/ isbn9789522653949.pdf?sequence $=2$.

KISPERSKA-Moroń, D. [2020]: The main factors determining position of women in contemporary logistics and supply chains. The Chartered Institute of Logistics and Transport UK. Kézirat, University of Economics in Katowice, Katowice, https://ciltuk.org.uk/LinkClick. aspx?fileticket $=$ gFCSsvwSCBE\%3D\&portalid $=0$.

Kramar, U.-Sternad, M.-Cvahte, T. [2015]: Logistics performance and its connection to competitiveness of the national economy in Slovenia and the Visegrad Group. European Perspectives - Slovenia's Role in Visegrad Group, Vol. 7. No. 2. 83-100. o. http://ceid.hu/ wp-content/uploads/2016/09/European-Perspectives3.pdf\#page=83. 
Lin, Y.-H.-Hong, C.-F. [2020]: Efficiency and effectiveness of airline companies in Taiwan and Mainland. Asia Pacific Management Review, Vol. 25. No. 1. 13-22. o. http://dx.doi. org/10.1016/j.apmrv.2019.04.002.

LiU, W.-WAn, Z.-WAN, Z.-Gong, B. [2020]: Sustainable recycle network of heterogeneous pharmaceuticals with governmental subsidies and service-levels of third-party logistics by bi-level programming approach. Journal of Cleaner Production, Vol. 249. http://dx.doi. org/10.1016/j.jclepro.2019.119324.

Luttermann, S.-Kotzab, H.-Halaszovich, T. [2020]: The impact of logistics performance on exports, imports and foreign direct investment. World Review of Intermodal Transportation Research, Vol. 9. No. 1. 27. o. http://dx.doi.org/10.1504/writr.2020.106444.

Molendowski, E.-ŻMudA, M. [2013]: Changes in Competitiveness among the Visegrad Countries after Accession to the European Union: A Comparative Analysis Based on a Generalized Double Diamond Model. Comparative Economic Research, Vol. 16. No. 4. 121-153. o. http://dx.doi.org/10.2478/cer-2013-0031.

Moroza, N.-Jurgelane-Kaldava, I. [2020]: Theoretical analysis of factors affecting the development of logistics centre. Economic Science for Rural Development Conference Proceedings. Jelgava, No. 53. 204-210. o. http://dx.doi.org/1022616/ESRD.2020.53.024.

Mukhitdinova, K.-Yuldasheva, S. [2020]: Development of transport and logistics services market. EPRA International Journal of Research and Development, Vol. 5. No. 5. 464-466. o. https://eprajournals.com/jpanel/upload/1131pm_99.EPRA\%20JOURNALS\%201652.pdf.

Porter, M. E. [1998]: Competitive advantage of nations. The Free Press, New York.

Pupavac, D.-Golubović, F. [2015]: Croatian competitiveness within european logistics space. Business Logistics in Modern Management, Vol. 15. 241-251. o.

RyguŁA, A.-Brzozowski, K.-Maczyński, A. [2020]: Limitations of the effectiveness of Weigh in Motion systems. Open Engineering, Vol. 10. 183-196. o. http://dx.doi.org/10.1515/ eng-2020-0020.

Schwaв, K. (szerk.) [2007-2019]: Global Competitiveness Report. World Economic Forum, Genf, http://reports.weforum.org/.

Scншав, K. (szerk.) [2019]: Global Competitiveness Report. World Economic Forum, Genf, http://www3.weforum.org/docs/WEF_TheGlobalCompetitivenessReport2019.pdf.

Shamsuzzoha, A. H. M.-Ehrs, M.-Tenkorang, R. A.-Nguyen, D.-Helo, P. T. [2013]: Performance evaluation of tracking and tracing for logistics operations. International Journal of Shipping and Transport Logistics, Vol. 5. No. 1. http://dx.doi.org/10.1504/ijstl.2013.050587.

Silva, I. J. A. D. [2019]: Análise da relação do Logistics Performance Index (LPI) e Global Competitiveness Index (GCI) no que tange à dimensão infraestrutura. Universidade Federal de Uberlândia, Uberlândia, https://repositorio.ufu.br/handle/123456789/27621.

Siudek, T.-Zawojska, A. [2014]: Competitiveness in the economic concepts, theories and empirical research. Oeconomia, Vol. 13. No. 1. 91-108. o. http://www.oeconomia.actapol. net/pub/13_1_91.pdf.

Tőrös Ágnes-MÉszÁros ÁdÁM-DAni Ákos [2016]: Investment Promotion in the Visegrad Countries: A Comparative Analysis. Megjelent: Szent-Iványi Balázs (szerk.): Foreign Direct Investment in Central and Eastern Europe. Studies in Economic Transition. Palgrave Macmillan, 193-217. o. http://dx.doi.org/10.1007/978-3-319-40496-7_9.

Veres LAjos (szerk.) [2015]: Logistics strategies in the visegrad countries: a comparative analysis. Magyar Logisztikai Egyesület, Budapest, http://v4log.eu/download/V4STUDYfinal.pdf. 
WEF [2007-2017]: The Global Competitiveness Index Historical Dataset, 2007-2017. World Economic Forum, http://www3.weforum.org/docs/GCR2017-2018/GCI Dataset_2007-2017.xlsx.

WŁodarczy K, A.-Mesjasz-Lech, A. [2019]: Development of Road Transport Logistic Infrastructure and Air Pollution in the Visegrad Group Countries. Journal of Economic and Social Development (JESD), Vol. 6. No. 1. 93-103. o. http://dx.doi.org/10.26352/ DJ02F5011.

WORLD BANK [2007-2018]: Full LPI Dataset. International LPI from 2007 to 2018. World Bank, https://lpi.worldbank.org/sites/default/files/International_LPI_from_2007_ to_2018.xlsx.

World BAnk [2020]: Doing Business, 2020. World Bank Group, Washington D.C. https:// openknowledge.worldbank.org/bitstream/handle/10986/32436/9781464814402.pdf.

Zekić, Z.-Samaržija, L.-Pupavac, J. [2017]: The Effect of Logistics Performance Index on Global Competitiveness Index at Different Levels of Economic Development. Interdisciplinary Management Research XIII, Faculty of Economics in Osijek-Hocjschule Pforzheim University, Opatija, 949-960. o. 